\title{
Annual hypoxia dynamics in an enclosed gulf
}

\section{K. Kountoura and I. Zacharias}

Department of Environmental and Natural Resources Management, University of Western Greece, Agrinio, Greece

Received: 22 March 2012 - Accepted: 3 April 2012 - Published: 25 April 2012

Correspondence to: I. Zacharias (izachari@cc.uoi.gr)

Published by Copernicus Publications on behalf of the European Geosciences Union.

Annual hypoxia dynamics in an enclosed gulf

K. Kountoura and I. Zacharias

\section{Title Page}

Abstract Introduction

Conclusions References

14

4

Back

Full Screen / Esc

Printer-friendly Version

Interactive Discussion 


\section{Abstract}

Hypoxia in coastal environments is a worldwide problem and is expected to worsen in future. Due to the stratification of the water column in many enclosed or semi-enclosed gulfs, deep waters are isolated and hypoxic or anoxic conditions frequently become 5 dominant. The most common method for the oxygenation of these isolated anoxic water masses is vertical mixing. However, there are enclosed gulfs which rarely have the appropriate energy to ensure the mixing of the entire water column. The main purpose of this paper is to find if there are any other hydrodynamic processes which can cause oxygenation of deep waters, apart from vertical mixing. In order to achieve this aim, an enclosed gulf, Amvrakikos in Western Greece, was chosen to be the case study area and bimonthly physicochemical data were collected for one year and used in combination with a three-dimensional model in order to simulate the hydrodynamic circulation of the system. According to our results, another hydrodynamic process can lead to the oxygenation of the deepest water in an enclosed gulf. This process is the horizontal the success of this horizontal intrusion is the density difference between the deepest area of the enclosed gulf and the open sea outside the gulf. From autumn to winter, when the open sea water is denser than that inside the gulf, the well oxygenated open sea water inflows into the gulf near the bottom sea floor and re-oxygenates the isolated deep waters through mixing. However, from spring to summer, when the deep water of the gulf is characterized by higher density in comparison with the open sea water, the inflow of well oxygenated water stops, causing the development of hypoxic/anoxic conditions during the summer months.

\section{Introduction}

25 Although early reports of anoxic events date back to earlier geological periods in the Permian-Triassic boundary (Kump et al., 2005), the problem of oxygen depletion has

5050
BGD

9, 5049-5071, 2012

Annual hypoxia dynamics in an enclosed gulf

K. Kountoura and I. Zacharias

Title Page

Abstract Introduction

Conclusions

Tables

References

Figures

14

4

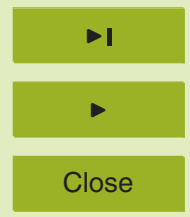

Back

Full Screen / Esc

Printer-friendly Version

Interactive Discussion 
reached a more global level today. In the present geological period, the first hypoxic / anoxic reports were recorded in 1910-1920 with fifteen to twenty coastal areas found affected (Zhang et al, 2010). By 2008, more than four hundred references had been recorded in scientific literature (Diaz and Rosenberg, 2008). It could be assumed that 5 this increase was a result of greater systematic research by scientists on the causes and impacts of hypoxia after the second half of the 19th century. However, there are strong indications that the dissolved oxygen concentrations will decrease significantly in the future and indeed many believe that the first indications of the future decline is already happening today. It has been estimated that the negative trend of DO concen10 trations has increased from 1951 to 2000 , while simultaneously it has been calculated that the future annual rate of DO decrease will be equal to $0.98 \mu_{\mathrm{mol} \mathrm{L}}^{-1}$ (Gilbert et al., 2010).

According to Pena et al. (2010), oxygen concentrations are maintained by the balance between biological oxygen production and consumption and exchanges between 15 atr atmosphere and sea and its transport. Any imbalance between the above factors can lead to the development of hypoxia, (oxygen concentrations less than $2 \mathrm{mg} \mathrm{L}^{-1}$ or $30 \%$ saturation) or anoxia (complete absence of oxygen). Among the most important causative agents which can cause this imbalance is the interaction between nutrient overload, resulting in eutrophication, low physical energy, fresh water inputs, stratification, changes in oceanic circulation, reduced winter ventilation, global warming, high residence time, and limited exchange and loss of sediment-buffering capacity (Druon et al., 2004; Gilbert et al., 2005; Conley et al., 2009; Kemp et al., 2009). Previously, hypoxia appeared due to natural causes in places like upwelling areas, oxygen minimum zones, deep basins and fjords. According to Diaz and Rosenberg (2008), from 251960 until today, human activities caused the intensification of hypoxic zones already in existence and the degradation of new areas, such as estuaries and coastal regions, to such an extent that new hypoxic or anoxic environments occurred rapidly.

Hypoxia affects ecosystems and organisms in different ways. Some of its most serious impacts are mass fish mortality, habitat loss, changes in bio-geochemistry

\section{BGD}

9, 5049-5071, 2012

Annual hypoxia dynamics in an enclosed gulf

K. Kountoura and I. Zacharias

Title Page

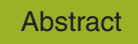

Introduction

Conclusions

Tables

References

Figures

14

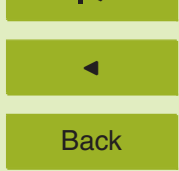

$>$ I

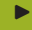

Close

Full Screen / Esc

Printer-friendly Version

Interactive Discussion 
processes, toxic gas release, and changes in sediment functioning (Conley et al., 2002) making the ecosystems more susceptible to further hypoxia. According to Conley et al. (2007), "once an ecosystem experiences hypoxia, it becomes more vulnerable to future hypoxic events". Severity and duration of hypoxia in combination with human 5 pressures and hydrodynamic processes are the major factors which govern the return of an ecosystem to its initial conditions, before the hypoxic event (Steckbauer et al., 2011).

It is common for stratified enclosed or semi-enclosed basins to have isolated bottom water masses which suffer from hypoxia and/or anoxia. In such systems the ventila10 tion of the bottom isolated water masses may occur because of wind stress which reduces the density gradient, resulting in the inflow of saltier water, such as in the Baltic Sea, (Jakobsen, 1995; Matthaus and Franck, 1992) or because of interactions with the spring-neap tidal cycle, such as in the Tokyo Bay or Ise Bay (Fujiwara and Yamada, 2002; Kasai et al., 2004). In either case the density of the waters outside the basin is the key factor (Zhang et al., 2010). The common trait of the above cases is that the ventilation is carried out either by adding physical energy to the system, via wind or tide, or by the intrusion of saltier water, yielding a salinity difference between the inside and outside of the basin. Another common factor is that these processes are completed in a short time period, from a few days to one or two weeks.

The oxygenation process is well documented in cases where vertical mixing takes place. However, a void in scientific literature exists in reference to the oxygenation of systems deficient in the energy required to yield vertical mixing. Our main question is how can oxygenation take place without vertical mixing? And, subsequently, why are oxygen levels measured at the sea floor are higher than in the water column above?

25 Also, what is causing this process? In this work we will try to answer the following questions: (1) Apart from vertical mixing, is there any other hydrodynamic process that produces the oxygenation of deep, isolated waters in enclosed gulfs, when physical energy is restricted? (2) How can this happen and what are the "key factors" limiting or strengthening this process? (3) Which is the general, annual circulation pattern of an

Annual hypoxia dynamics in an enclosed gulf

K. Kountoura and I. Zacharias

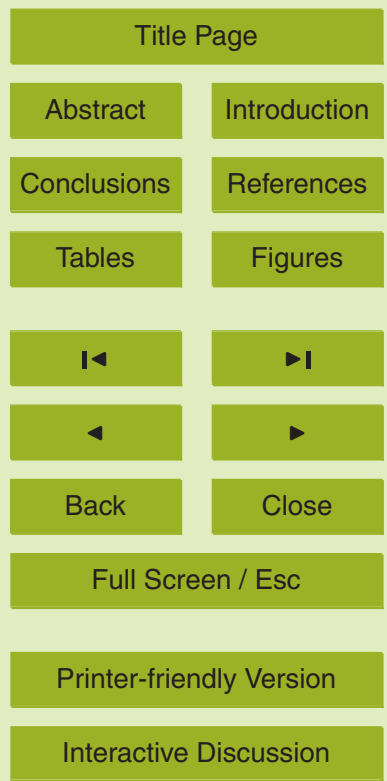


isolated hypoxic/anoxic zone in such a system? In order to achieve this aim, the authors will use as a case study the enclosed gulf of Amvrakikos Gulf in Western Greece, using a year of measurements and a three-dimensional numerical model for the simulation of the hydrodynamic circulation.

\section{Materials and methods}

\subsection{Study area}

The Amvrakikos Gulf is a typical semi-enclosed gulf situated in north-western Greece consisting of complex morphological and hydrographic conditions. It is separated from the Ionian Sea by a beach barrier complex and its only connection with the open sea is 10 through a narrow strait, $600 \mathrm{~m}$ wide, $3 \mathrm{~km}$ long and $8.5 \mathrm{~m}$ deep (Kapsimalis et al., 2005). It is $35 \mathrm{~km}$ long, its width varies from 5 to $15 \mathrm{~km}$, it has a surface area of $405 \mathrm{~km}^{2}$, and its total volume is equal to $10.2 \mathrm{~km}^{3}$. The gulf's mean depth is $26 \mathrm{~m}$, and its maximum depth does not exceed $63 \mathrm{~m}$ (Fig. 1).

The main feature of this basin is the limited exchange of water with the open sea 15 (Ionian Sea) due to the narrow opening of the inlet (Preveza channel) in the entrance of the gulf. Additionally, due to the substantial impact of fresh water from the Arachthos and Louros Rivers, in the study area and the high temperatures during summer, the water column is strongly stratified throughout most of the year. This, in combination with low physical energy (description in chapter 3.1), is the major factor that hinders vertical mixing of the water column. These factors result in predominantly eutrophic conditions in the study area and lead to the development of a hypoxic/anoxic zone near the bottom (Kountoura and Zacharias, 2011).

The hypoxic conditions in the study area have been known since 1987 (Friligos et al., 1989), but the first research efforts to highlight the extent and the severity of the problem only began in recent years (Kountoura and Zacharias, 2011; Ferentinos et al., 2010).
BGD

9, 5049-5071, 2012

Annual hypoxia dynamics in an enclosed gulf

K. Kountoura and I. Zacharias

Title Page

Abstract Introduction

Conclusions

Tables Figures

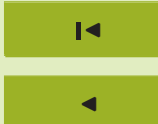

- I

Back

Close

Full Screen / Esc

Printer-friendly Version

Interactive Discussion 


\subsection{Field observations}

The collection of the physicochemical data which were necessary for the purposes of this investigation was carried out during 2010-2011. Specifically, seven samples were collected at nine sampling stations in two month intervals, from September 2010 to

5 July 2011. The spatial configuration of the sampling stations formed a transect starting in the western part of the gulf (station $\mathrm{AM}_{1}$ ), covering the central part and finishing in the eastern, deeper area of the Amvrakikos Gulf (station $\mathrm{AM}_{9}$ ) (Fig. 1). Using a multiparameter unit, Level TROLL 9500, by In-Situ Inc., water characteristics such as temperature, depth, $\mathrm{pH}, \mathrm{ORP}$, dissolved oxygen, conductivity, and salinity were measured

\subsection{Hydrodynamic model}

To achieve the targets of this research, the authors used the MIKE 3 Flow Model FM, HD by DHI Water \& Environment, in order to simulate the hydrodynamic circulation in enclosed basins with limited physical energy. It is a three-dimensional numerical model which simulates unsteady flow taking into account density variations, bathymetry, and external forcing.

The modelling system is based on the numerical solution of the three-dimensional incompressible Reynolds averaged Navier-Stokes equations subject to the assumptions of Boussinesq and of hydrostatic pressure. Thus, the model consists of continuity, mo-

mentum, temperature, salinity, and density equations and it is closed by a turbulent closure scheme. The density does not depend on the pressure, but only on the temperature and the salinity.

The local continuity equation is written as:

$\frac{\partial u}{\partial x}+\frac{\partial v}{\partial y}+\frac{\partial w}{\partial z}=S$
BGD

$9,5049-5071,2012$

Annual hypoxia dynamics in an enclosed gulf

K. Kountoura and I. Zacharias

Title Page

Abstract Introduction

Conclusions

Tables References Figures

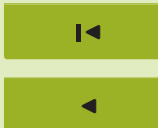

- I

Back

Close

Full Screen / Esc

Printer-friendly Version

Interactive Discussion 
and the two horizontal momentum equations for the $\mathrm{x}$ - and $\mathrm{y}$-component are, respectively:

BGD

$\frac{\partial u}{\partial t}+\frac{\partial u^{2}}{\partial x}+\frac{\partial v u}{\partial y}+\frac{\partial w u}{\partial z}=f v-g \frac{\partial \eta}{\partial x}-\frac{1}{p_{0}} \frac{\partial p_{a}}{\partial x}-\frac{g}{p_{0}} \int_{z}^{\eta} \frac{\partial p}{\partial x} d z+F_{u}+\frac{\partial}{\partial z}\left(v_{t} \frac{\partial u}{\partial z}\right)+u_{s} S$

$$
\frac{\partial v}{\partial t}+\frac{\partial v^{2}}{\partial y}+\frac{\partial u v}{\partial x}+\frac{\partial w v}{\partial z}=-f u-g \frac{\partial \eta}{\partial y}-\frac{1}{p_{0}} \frac{\partial p_{a}}{\partial y}-\frac{g}{p_{0}} \int_{z}^{\eta} \frac{\partial p}{\partial y} d z+F_{v}+\frac{\partial}{\partial z}\left(v_{t} \frac{\partial v}{\partial z}\right)+v_{s} S
$$

However, the calculations of the transports of temperature, $T$, and salinity, $s$ follow the general transport-diffusion equations as:

${ }_{10} \frac{\partial T}{\partial t}+\frac{\partial u T}{\partial x}+\frac{\partial v T}{\partial y}+\frac{\partial w T}{\partial z}=F_{T}+\frac{\partial}{\partial z}\left(D_{v} \frac{\partial T}{\partial z}\right)+H+T_{s} S$

$\frac{\partial s}{\partial t}+\frac{\partial u s}{\partial x}+\frac{\partial v s}{\partial y}+\frac{\partial w s}{\partial z}=F_{s}+\frac{\partial}{\partial z}\left(D_{v} \frac{\partial s}{\partial z}\right)+H+s_{s} S$

And the horizontal diffusion terms are defined by:

$\left(F_{T}, F_{s}\right)=\left[\frac{\partial}{\partial x}\left(D_{h} \frac{\partial}{\partial x}\right)+\frac{\partial}{\partial y}\left(D_{h} \frac{\partial}{\partial y}\right)\right](T, s)$

The spatial discretization of the primitive equations is performed using a cell-centred finite volume method. In the horizontal plane, an unstructured mesh is used while a structured mesh is used in the vertical domain of the model and the elements can be prisms or bricks whose horizontal faces are triangles and quadrilateral elements, respectively (DHI, 2007).

9, 5049-5071, 2012

Annual hypoxia dynamics in an enclosed gulf

K. Kountoura and

I. Zacharias

Title Page

Abstract

Introduction

Conclusions

References

Tables

Figures

14

4

Back

Close

Full Screen / Esc

Printer-friendly Version

Interactive Discussion 


\subsection{Model inputs}

To achieve the best simulation, the appropriate information was entered into the model. Specifically, the data were related to morphometric, initial and boundary conditions, and meteorological and hydrographic data. A map of the study area with a scale of

5 1:50.000 was used in order to extract the appropriate information about bathymetry and the computational mesh. The model consisted of 8.414 elements, and an unstructured mesh in the horizontal plane, while in the vertical plane, a combination of 12 equidistant sigma-layers (1 $\mathrm{m}$ interval) and 10 equidistant z-layers (3.9 m interval) were apparent.

In the computational domain there was only one open boundary, the Preveza chan10 nel, the only connection between the Amvrakikos Gulf and the Ionian Sea, and for this the boundary temperature, salinity and sea level were determined. For this a waterlevel sensor, Level TROLL-500 by In-Situ Inc., was positioned in the area near the entrance which monitored and stored a timed series of data including sea level and temperature from July 2008 to July 2011, at a 15 min interval. For the definition of the initial conditions in reference to water temperature and salinity, measurements from the monthly samplings as were described in Sect. 2.2 were used. In addition, climatological data such as wind speed and direction, precipitation, air-temperature, and air-humidity, which were necessary for the simulation, were collected from a weather station established by the authors in the area of Aktio, and recorded from 2008 until 2011, at a 15 min interval.

\subsection{Model calibration}

In order to calibrate the MIKE 3 HD model, the temperature and salinity measurements from the samplings in January 2011 were used as the initial conditions for the simulation. The observations from the samplings in February 2011 have been used as the verification data. The results of the model's calibrations from two sampling stations (one in the western end and one in the eastern end of the gulf) are presented in Fig. 2. With regard to salinity, the hydrodynamic model can conserve the stratification of the

BGD

9, 5049-5071, 2012

Annual hypoxia dynamics in an enclosed gulf

K. Kountoura and I. Zacharias

Title Page

Abstract Introduction

Conclusions

Tables References Figures

14

4

Back

Close

Full Screen / Esc

Printer-friendly Version

Interactive Discussion 
water column for long periods and it simulates quite well the boundaries of the halocline which developed to the depth of $10 \mathrm{~m}$ and $12 \mathrm{~m}$, in the western and eastern parts of the gulf, respectively, and also the range of salinity both in halocline and in the layer below it. In reference to temperature, and according to Fig. $2 b$ which presents the simulated 5 and observed temperature conditions at two different stations in Amvrakikos Gulf, it is clear that it can simulate the temperature conditions in the western part of the gulf. In the eastern part of the gulf, the model can simulate the distribution of the temperature; however the range of observed temperatures is slightly different than the measured data. Finally, according to Fig. $2 \mathrm{c}$ we can observe that the simulated surface elevation 10 is almost the same as that measured in the Loutraki region in 2011. In conclusion, we can assume that MIKE $3 \mathrm{HD}$, which has been used for the purpose of this study, is able to simulate the circulation and stratification patterns which dominated the Amvrakikos Gulf.

\section{Results}

\subsection{Description of an enclosed gulf with low physical energy}

Figure 3 describes the climatological and hydrographical conditions which dominate an enclosed gulf with low physical energy, such as Amvrakikos. According to this, neither tide nor wind provides the system with the appropriate energy required to mix the water column. Specifically, Fig. 3a, describes the surface elevation at the mouth of the gulf. According to this, the tidal range is microtidal throughout the year, with less than $0.48 \mathrm{~m}$ mean range, while the maximum and minimum level is equal to $0.9 \mathrm{~m}$ and $0.15 \mathrm{~m}$ respectively. Simultaneously, because frictional effect exceeds convergence effect, hyposychronous conditions dominate in the system and, as a result, the tidal range decreases from mouth to head, while the maximum tidal currents are detected only in the area near the mouth.
BGD

$9,5049-5071,2012$

Annual hypoxia dynamics in an enclosed gulf

K. Kountoura and I. Zacharias

Title Page

Abstract Introduction

Conclusions

Tables References Figures

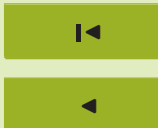

- I

Back

Close

Full Screen / Esc

Printer-friendly Version

Interactive Discussion 
The key factor that restricts vertical mixing in an enclosed gulf is stratification. Fig. 3c, describes the salinity, temperature and density conditions in such a gulf. It is clearly visible that the gulf is strongly stratified throughout the year. The stratification is even sharper due to high temperature differences from season to season. This, in combi5 nation with the high salinity gradient, leads to the development of a strong pycnocline (Fig. $3 c$ ) which exists in the water column throughout the year and thus eliminates mixing.

Another important reason for the mixing limitation is the mild weather conditions which dominate in the area. According to climatological data, the dominant wind speed 10 is equal to $4-5 \mathrm{~ms}^{-1}$, while, as Fig. $3 \mathrm{~b}$ shows, the highest wind speed is rarely higher than $10 \mathrm{~ms}^{-1}$, even during winter. Taking into account the special stratification conditions which dominate this system and the low wind speed throughout the year, it is evident that the appropriate hydrological and meteorological conditions required for vertical mixing rarely occur.

\subsection{Movement of the anoxic zone}

Figure 4 represents the longitudinal distribution of density in the enclosed gulf during the year. According to this, during summer, the water column is strongly stratified, as a strong pycnocline exists at a depth of about $5 \mathrm{~m}$. As a result, the bottom layer is isolated from mixing with the highly oxygenated surface water. Furthermore, because 20 the decomposition of organic matter is higher during this season, the consumption of dissolved oxygen near the bottom is high. The combination of these two factors leads to the development of a hypoxic and/or anoxic zone near the bottom of the entire gulf (Fig. 5), which from now on will be referred as "Bottom Hypoxic Water Zone" (BHWZ). Simultaneously, as it is shown in Fig. 4, during the summer period the surface Open 25 Sea Water Mass (OSWM) outside the enclosed gulf is less dense than the water mass existing in the deepest area of the gulf. This density difference does not allow the OSWM to flow into the enclosed bay in order to enrich the bottom waters with oxygen,
BGD

9, 5049-5071, 2012

Annual hypoxia dynamics in an enclosed gulf

K. Kountoura and I. Zacharias

Title Page

Abstract Introduction

Conclusions

Tables References Figures

14

4

Back

Full Screen / Esc

Printer-friendly Version

Interactive Discussion

\section{8}


and thus the dissolved oxygen concentration, in the BHWZ, remains very low throughout the summer.

During autumn the OSWM is characterized by high dissolved oxygen concentrations (DO $=7-8 \mathrm{mg} \mathrm{L}^{-1}$ ) and high salinity (38-40 PSU), so its density is sufficiently high

$5 \quad\left(\sigma_{t}>27.5\right)$. At the same time, the density of both the surface and the deepest layer of the enclosed gulf are less than 27.5 (Fig. 4) and, as a result, the heavier OSWM flows into the enclosed gulf near the bottom layer. This is also confirmed by the T-S diagrams in Fig. 6a. As this figure shows, during autumn (November) the OSWM, which exists in the entrance of the gulf, below the depth of $10 \mathrm{~m}$, is also detected in the rest of the gulf, 10 at higher depths. Thus, the OSWM entered in the enclosed gulf through the deepest layer of st. $\mathrm{AM}_{1}$, and moved into the rest of the gulf in middle depths through the st. $\mathrm{AM}_{5}$ (between the depth of $17 \mathrm{~m}$ and $21 \mathrm{~m}$ ) and then through the st. $\mathrm{AM}_{8}$ in the eastern part of the gulf (between the depth of $15 \mathrm{~m}$ and $19 \mathrm{~m}$ ). As it is shown in Fig. 5, which describes the annual distribution of dissolved oxygen in an enclosed gulf, the inflow of the well oxygenated OSWM causes changes in oxygen conditions only in the area where it inflows near the bottom. When this occurs, the OSWM oxygenates the water near the bottom and thus the BHWZ seems to disappear gradually from this area. However, when the OSWM inflows through the middle depths, as it happens during autumn in the rest of the enclosed gulf, does not affect the DO concentrations of the BHWZ.

During winter, the OSWM continues to have greater density in comparison to the water inside the gulf (Fig. 4). As the OSWM continues to flow into the gulf near the bottom, the BHWZ moves towards the surface of the water column. However, due to the strong pycnocline which exists in the water column, the BHWZ cannot pass this layer and is trapped below it. As a result, during winter, in the vertical distribution of DO (Fig. 5), the BHWZ seems to be a thin layer of water with anoxic conditions is suspended in an intermediate depth of the water column, just below the pycnocline. In particular, the depth of this intermediate layer varies with the intrusion affection. Near the entrance of the gulf where the effect of OSWM lasts for a longer time period,

BGD

$9,5049-5071,2012$

Annual hypoxia dynamics in an enclosed gulf

K. Kountoura and I. Zacharias

Title Page

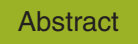

Introduction

Conclusions

Tables

References

Figures

14

4

Back

Full Screen / Esc

Printer-friendly Version

Interactive Discussion 
the BHWZ occupies only a few meters of the water column just below the pycnocline. However, as one moves toward to the head of the gulf, where the influence of OSWM lasts for shorter time period, the BHWZ occupies a greater depth of the water column (Fig. 5).

$5 \quad$ According to model results (Fig. 7) at the end of winter, the denser OSWM is still moving to the main gulf near the bottom while near the surface the water is moving toward either the open sea or the enclosed gulf in following the tide. Under other circumstances, the oxygenation of the bottom water and the movement of the anoxic zone would have lasted only a few hours or days, as it happened in other case stud10 ies (Kasai et al., 2004, Fujiwara and Yamada, 2002). In this study, as Fig. 4 shows, the density difference between the open sea water and the enclosed gulf is not very high (almost equal to 0.5), thus preventing the OSWM from moving rapidly toward to the gulf's head. This, in combination with the very low physical energy of the system and the very low current speed (as they are rarely higher than $0.05 \mathrm{~m} \mathrm{~s}^{-1}$ ), makes this 15 process particularly time-consuming; lasting for almost 6 months.

After the period of OSWM intrusion, there are changes on the oxygenation conditions in the bottom layer of the enclosed gulf. The OSWM, which until now was near the bottom, has mixed completely with the deep water mass of the bay (which existed under the pycnocline). This mixing significantly affects the dissolved oxygen concentrations and the densities inside the gulf. Thus, as Fig. 5 shows, this mixing causes the oxygenation of the entire water column, almost throughout the whole gulf. This results in the disappearance of the BHWZ, and DO concentrations (more than $1 \mathrm{mg} \mathrm{L}^{-1}$ ) appearing only in a thin layer, very close to the bottom. In addition to this, with the mixing of the two water masses a new water mass (NWM) is developed, with a density greater ${ }_{25}\left(\sigma_{t}>28\right.$, Fig. 6b) than the densities of the two initial water masses.

\section{BGD}

$9,5049-5071,2012$

Annual hypoxia dynamics in an enclosed gulf

K. Kountoura and I. Zacharias

Title Page

Abstract Introduction

Conclusions

Tables References Figures

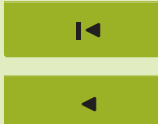

$\rightarrow 1$

Back

Close

Full Screen / Esc

Printer-friendly Version

Interactive Discussion 


\section{Conclusions}

The present study deals with the annual dynamics of the hypoxic/anoxic zone and the driving forces behind this. As a case study, an enclosed gulf in Western Greece was chosen, with low physical energy as a result of the small tidal amplitude and soft 5 winds. The main characteristic of this enclosed gulf is that the water column is strongly stratified throughout the year due to high density gradients. As a result, vertical mixing of the water column is almost impossible, causing the isolation of the bottom layer and therefore the presence of hypoxic and/or anoxic conditions near the bottom. According to our results, it is obvious, that in enclosed gulfs, where the vertical mixing of the water column is difficult, the oxygenation of the bottom layer of water takes place, due to the horizontal inflow of oxygenated open sea water masses.

According to our study, the key factor for the oxygenation of bottom water is the density gradient between the water near the bottom, inside the basin, and the open sea outside: the denser the seawater is, the higher the driving force, causing the intrusion of well oxygenated seawater. The water density inside the gulf is what causes the interruption of oxygenation. As Fig. 8 shows, the intrusion of seawater at higher depths begins in autumn, when the seawater is denser than that near the bottom inside the enclosed gulf, and lasts until the end of winter, when the water inside the gulf becomes denser than the seawater. However, the density difference inside and outside the enclosed gulf, in combination with current speed, are the two factors which control the time required for the oxygenation of bottom water inside the gulf. These factors can either strengthen or weaken this process, since the greater the density difference, the faster the inflow of well oxygenated water will be and, therefore, the faster the oxygenation of the isolated layer will be.
BGD

$9,5049-5071,2012$

Annual hypoxia dynamics in an enclosed gulf

K. Kountoura and I. Zacharias

Title Page

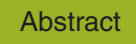

Introduction

Conclusions

Tables

References

Figures

14

4

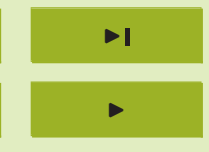

Back

Close

Full Screen / Esc

Printer-friendly Version

Interactive Discussion 


\section{References}

Conley D. J., Humborg, C., Rahm, L., Savchuk, O. P., and Wulff, F.: Hypoxia in the Baltic Sea and basin-scale changes in phosphorus biogeochemistry, Environ. Sci. Tecnhol., 36, 53155320, 2002.

5 Conley, D. J., Carstensen, J., Vaquer-Sunyer, R., and Duarte, C. M.: Ecosystem thresholds with hypoxia, Hydrobiologia, 629, 21-29, 2009.

DHI: MIKE 3 Flow Model FM, Hydrodynamic module - User Guide, DHI, Software, 2007.

Diaz, R. J. and Rosenberg, R.: Spreading dead zones and consequences for marine ecosystems, Science, 321, 926-929, 2008.

Druon, J., Schrimpf, W., Dobricic, S., and Stips, A.: Comparative assessment of large-scale marine eutrophication: North Sea area and Adriatic Sea as case studies, Mar. Ecol.-Prog. Ser., 272, 1-23, 2004.

Ferentinos, G., Papatheodorou, G., Geraga, M., latrou, M., Fakiris, E., Christodoulou, D., Dimitriou, E., and Koutsikopoulos, C.: Fjord water circulation patterns and dysoxic/anoxic conditions in a Mediterranean semi-enclosed embayment in the Amvrakikos Gulf, Greece, Estuarine, Coastal and Shelf Science, 88, 473-481, 2010.

Friligos, N., Psilidou, R., Xatzigewrgiou, E., Pappas, G.: Seasonal variations on nutrients and dissolved oxygen, in: Oceanographic study of the Amvrakikos Gulf, edited by: Tsiavos, Ch., Chemical Oceanography, 3, Final Report. Athens, Greece, 1989(in Greek).

Fujiwara, T. and Yamada, Y.: Inflow of oceanic water into Tokyo Bay and generation of a subsurface hypoxic water mass, J. Geophys. Res., 107, 1-9, 2002.

Gilbert, D., Sundby, B., Gobeil, C., Mucci, A., and Tremblay, G. H.: A seventy-two-year record of diminishing deep-water oxygen in the St. Lawrence estuary: The northwest Atlantic connection, Limnol. Oceanogr., 50, 1654-1666, 2005.

25 Gilbert, D., Rabalais, N. N., Díaz, R. J., and Zhang, J.: Evidence for greater oxygen decline rates in the coastal ocean than in the open ocean, Biogeosciences, 7, 2283-2296, doi:10.5194/bg7-2283-2010, 2010.

Jakobsen, F.: The major inflow to the Baltic Sea during January 1993, J. Marine Syst., 6, 227240, 1995.

30 Kapsimalis, V., Pavlakis, P., Poulos, S. E., Alexandri, S., Tziavos, C., Sioulas, A., Filippas, D., and Lyskousis, V.: Internal structure and evolution of the Late Quaternary sequence in a shallow embayment: the Amvrakikos Gulf, NW Greece, Mar. Geol., 222/223, 399-418, 2005.
BGD

9, 5049-5071, 2012

\section{Annual hypoxia dynamics in an enclosed gulf}

K. Kountoura and I. Zacharias

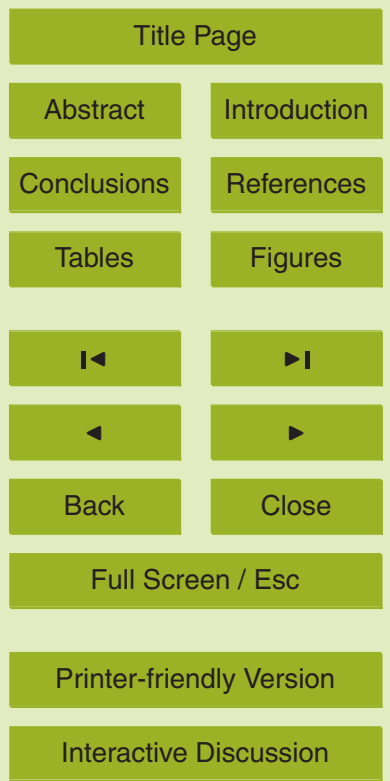


Kasai, A., Fujiwara, T., Kimura, T., and Yamada, H.: Fortnightly shifts of intrusion depth of oceanic water into Ise Bay, J. Oceanogr., 60, 817-824, 2004.

Kemp, W. M., Testa, J. M., Conley, D. J., Gilbert, D., and Hagy, J. D.: Temporal responses of coastal hypoxia to nutrient loading and physical controls, Biogeosciences, 6, 2985-3008,

5 doi:10.5194/bg-6-2985-2009, 2009.

Kountoura, K. and Zacharias, I.: Temporal and spatial distribution of hypoxic/seasonal anoxic zone in Amvrakikos Gulf, Western Greece, Estuarine, Coastal and Shelf Science, 94, 123128, 2011.

Kump, L. R., Pavlov, A., and Arthur, M. A.: Massive release of hydrogen sulfide to the surface ocean and atmosphere during intervals of oceanic anoxia, Geology, 33, 397-400, 2005.

Matthaus, W. and Franck., H.: Characteristics of major Baltic inflows-a statistical analysis, Cont. Shelf Res., 12, 1375-1400, 1992.

Peña, M. A., Katsev, S., Oguz, T., and Gilbert, D.: Modeling dissolved oxygen dynamics and hypoxia, Biogeosciences, 7, 933-957, doi:10.5194/bg-7-933-2010, 2010.

Picard, G. L. and Emery, W. J.: Descriptive physical oceanography, in introduction, Pergamon Press, Oxford, 1982.

Steckbauer, A., Duarte, C. M., Carstensen, J., Vaquer-Sunyer, R., and Conley, D. J.: Ecosystem impacts of hypoxia: thresholds of hypoxia and pathways to recovery, Environ. Res. Lett., 6, 1-12, 025003, doi:10.1088/1748-9326/6/2/025003, 2011.

20 Zhang, J., Gilbert, D., Gooday, A. J., Levin, L., Naqvi, S. W. A., Middelburg, J. J., Scranton, M., Ekau, W., Peña, A., Dewitte, B., Oguz, T., Monteiro, P. M. S., Urban, E., Rabalais, N. N., Ittekkot, V., Kemp, W. M., Ulloa, O., Elmgren, R., Escobar-Briones, E., and Van der Plas, A. K.: Natural and human-induced hypoxia and consequences for coastal areas: synthesis and future development, Biogeosciences, 7, 1443-1467, doi:10.5194/bg-7-1443-2010, 2010.

BGD

$9,5049-5071,2012$

\section{Annual hypoxia dynamics in an enclosed gulf}

K. Kountoura and I. Zacharias

\section{Title Page}

Abstract Introduction

Conclusions

Tables

References

Figures

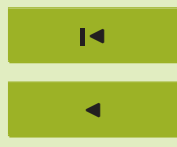

- I

Back

Close

Full Screen / Esc

Printer-friendly Version

Interactive Discussion 


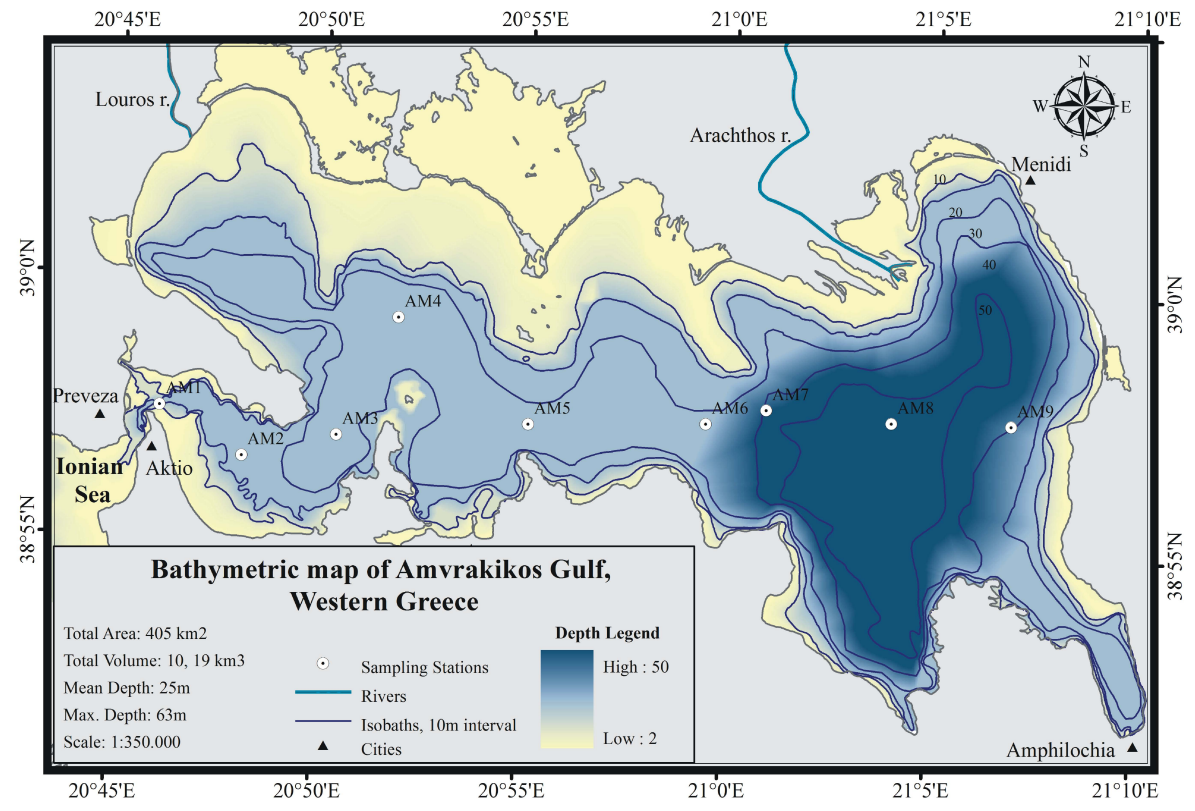

\section{BGD}

9, 5049-5071, 2012

Annual hypoxia dynamics in an enclosed gulf

K. Kountoura and I. Zacharias

Title Page

Abstract

Introduction

Conclusions

References

Tables

Figures

14

4

Back

Close

Full Screen / Esc

Printer-friendly Version

Interactive Discussion 
BGD

9, 5049-5071, 2012
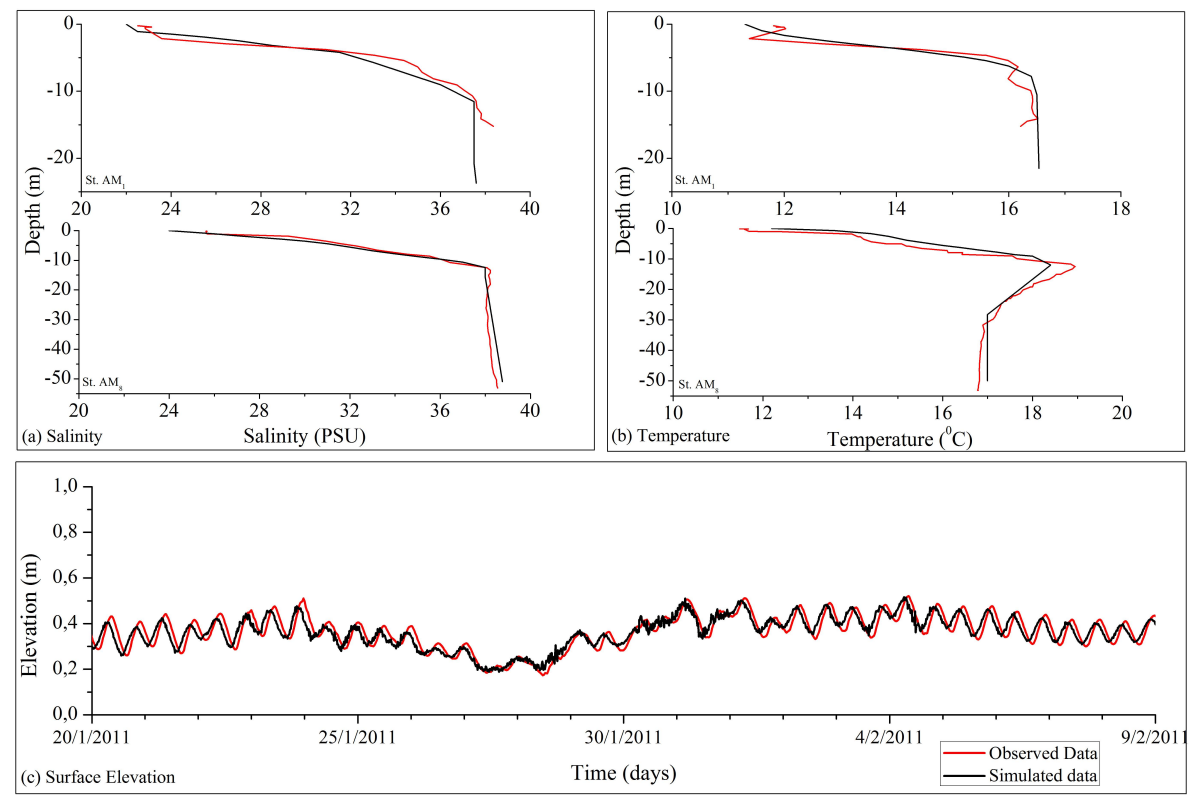

Fig. 2. Observed and simulated (a) salinity, (b) temperature at stations $A M_{1}$ and $A M_{8}$, and (c) surface elevation at Loutraki.

Annual hypoxia dynamics in an enclosed gulf

K. Kountoura and I. Zacharias

Title Page

Abstract Introduction

Conclusions

References

Tables

Figures

14

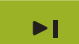

4

Back

Close

Full Screen / Esc

Printer-friendly Version

Interactive Discussion 

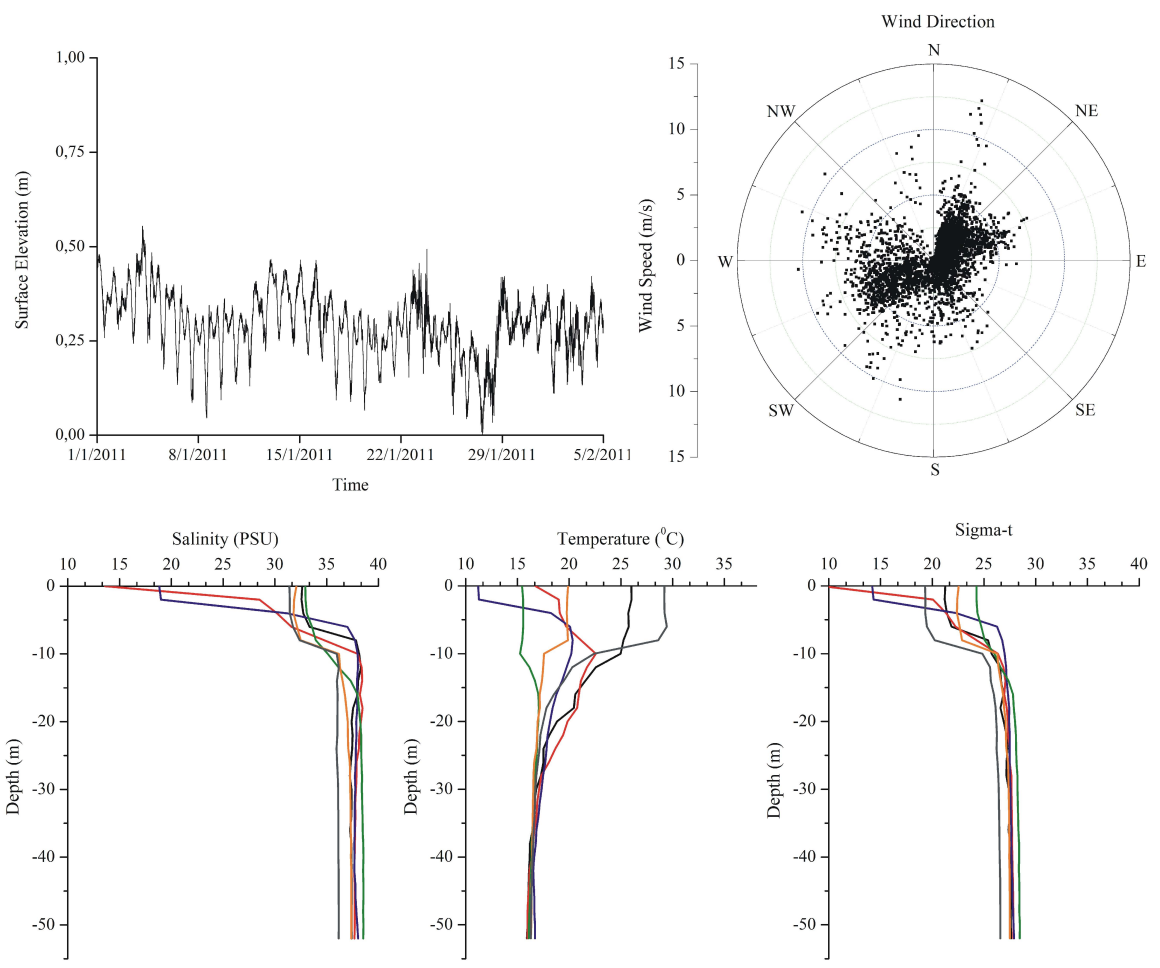

— Semptember '10 — November' 10 — January '11 — March''11 — May' '11 — July '11

Fig. 3. Hydrographical and climatological conditions in Amvrakikos gulf. (a) Surface elevation at the mouth of the gulf, (b) annual wind speed and direction, and (c) salinity, temperature and density $\left(\sigma_{t}\right)$ distribution at station $\mathrm{AM}_{8}$.

\section{BGD}

\section{$9,5049-5071,2012$}

Annual hypoxia dynamics in an enclosed gulf

K. Kountoura and

I. Zacharias

Title Page

Abstract

Introduction

Conclusions

References

Tables

Figures

14

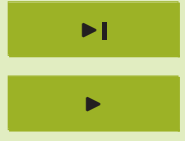

Back

Close

\section{Full Screen / Esc}

Printer-friendly Version

Interactive Discussion 

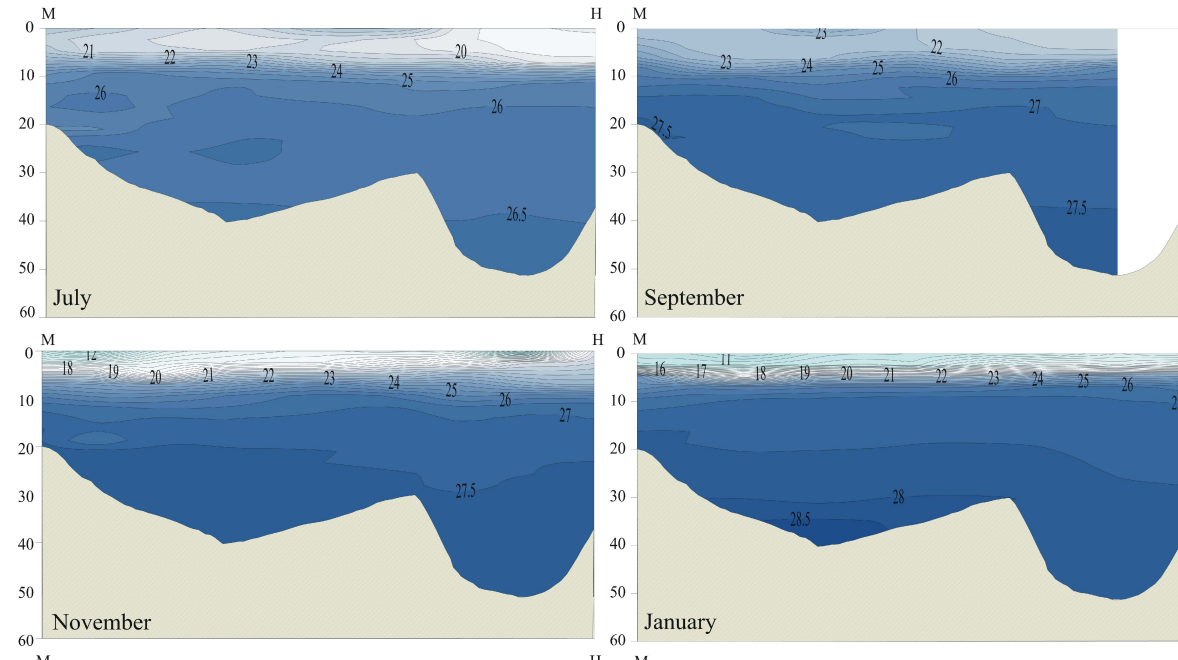

${ }^{\mathrm{H}}{ }_{0} \mathrm{M}$
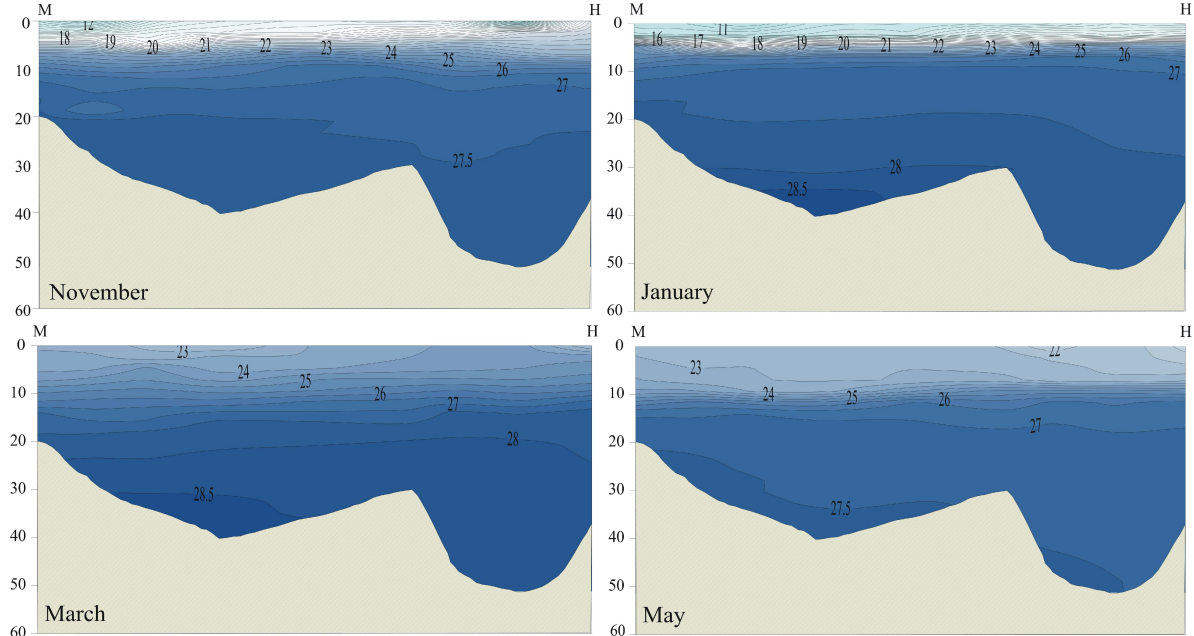

Fig. 4. Longitudinal distribution of density $\left(\sigma_{t}\right)$ during the year, from the mouth (station $\mathrm{AM}_{1}$ ) to the head (station $\mathrm{AM}_{8}$ ) of the enclosed gulf (the case study of Amvrakikos Gulf).

BGD

$9,5049-5071,2012$

Annual hypoxia dynamics in an enclosed gulf

K. Kountoura and I. Zacharias

Title Page

\section{Abstract}

Conclusions

\section{Tables}

14

4

Back

Full Screen / Esc

Printer-friendly Version 

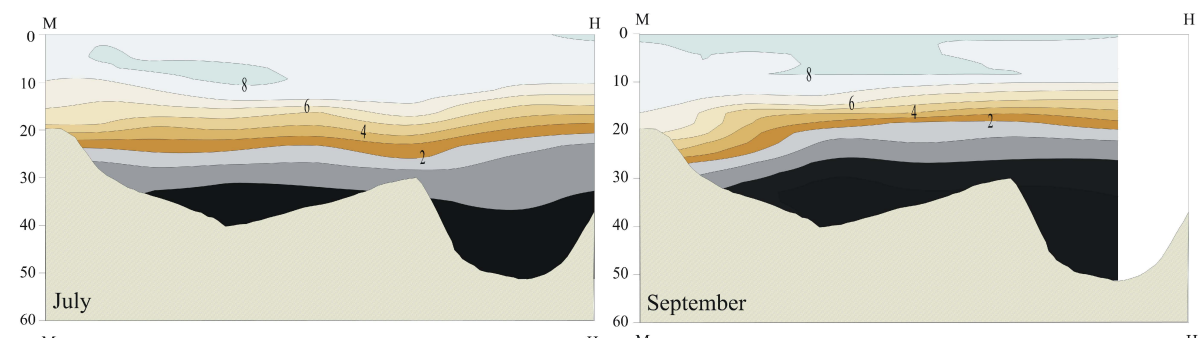

BGD

9, 5049-5071, 2012

Annual hypoxia dynamics in an enclosed gulf

K. Kountoura and I. Zacharias
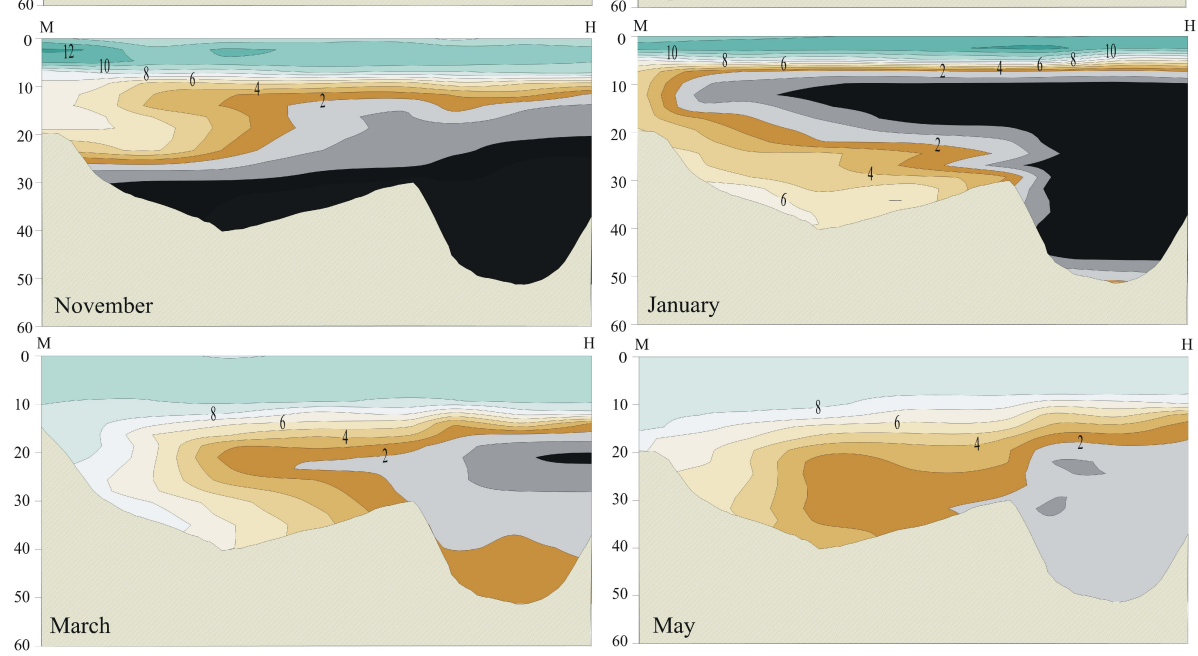

Fig. 5. The annual distribution of dissolved oxygen in $\mathrm{mg} \mathrm{L}^{-1}$ from bay's mouth $\left(\mathrm{M}\right.$, station $\left.\mathrm{AM}_{1}\right)$ to the head $\left(H\right.$, station $\left.A M_{9}\right)$.

Title Page

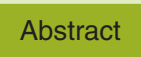

Introduction

Conclusions

References

Tables

Figures

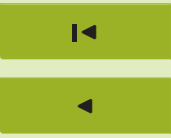

- I

Back

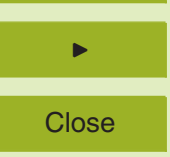

Full Screen / Esc

Printer-friendly Version

Interactive Discussion 

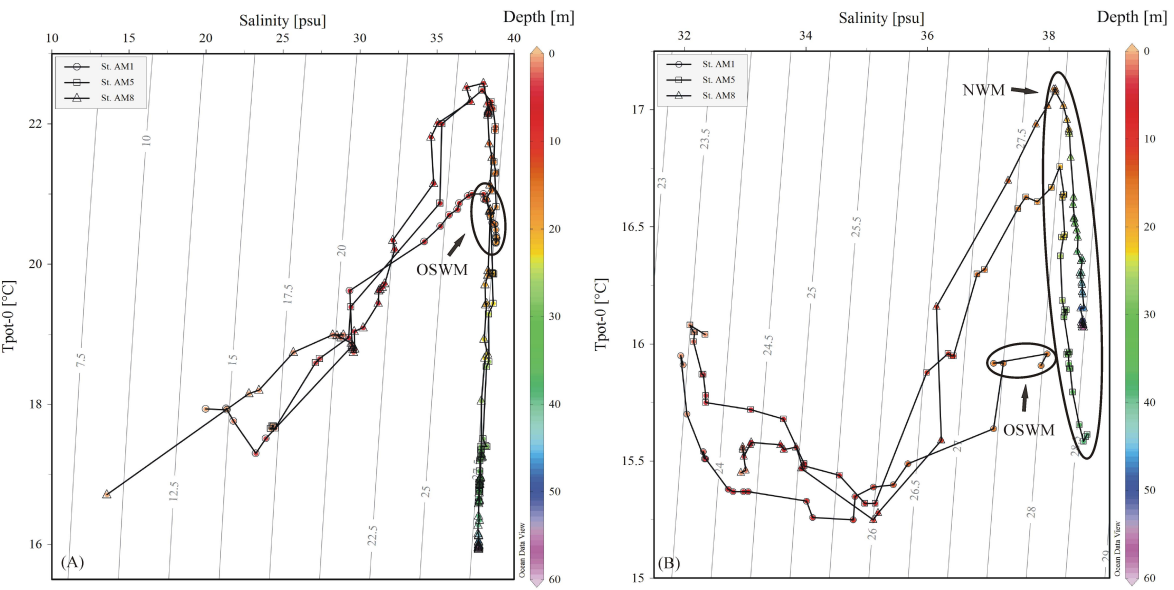

Fig. 6. Temperature-Salinity diagrams on (a) autumn (November 2010, stations $A M_{1}, A M_{5}$ and $\mathrm{AM}_{8}$ and (b) spring (March 2011, stations $\mathrm{AM}_{1}, \mathrm{AM}_{5}$ and $A M_{8}$ ).

BGD

9, 5049-5071, 2012

Annual hypoxia dynamics in an enclosed gulf

K. Kountoura and I. Zacharias

Title Page

Abstract Introduction

Conclusions

References

Tables

Figures

14

$>1$

4

Back

Close

Full Screen / Esc

Printer-friendly Version

Interactive Discussion 


\section{BGD}

9, 5049-5071, 2012
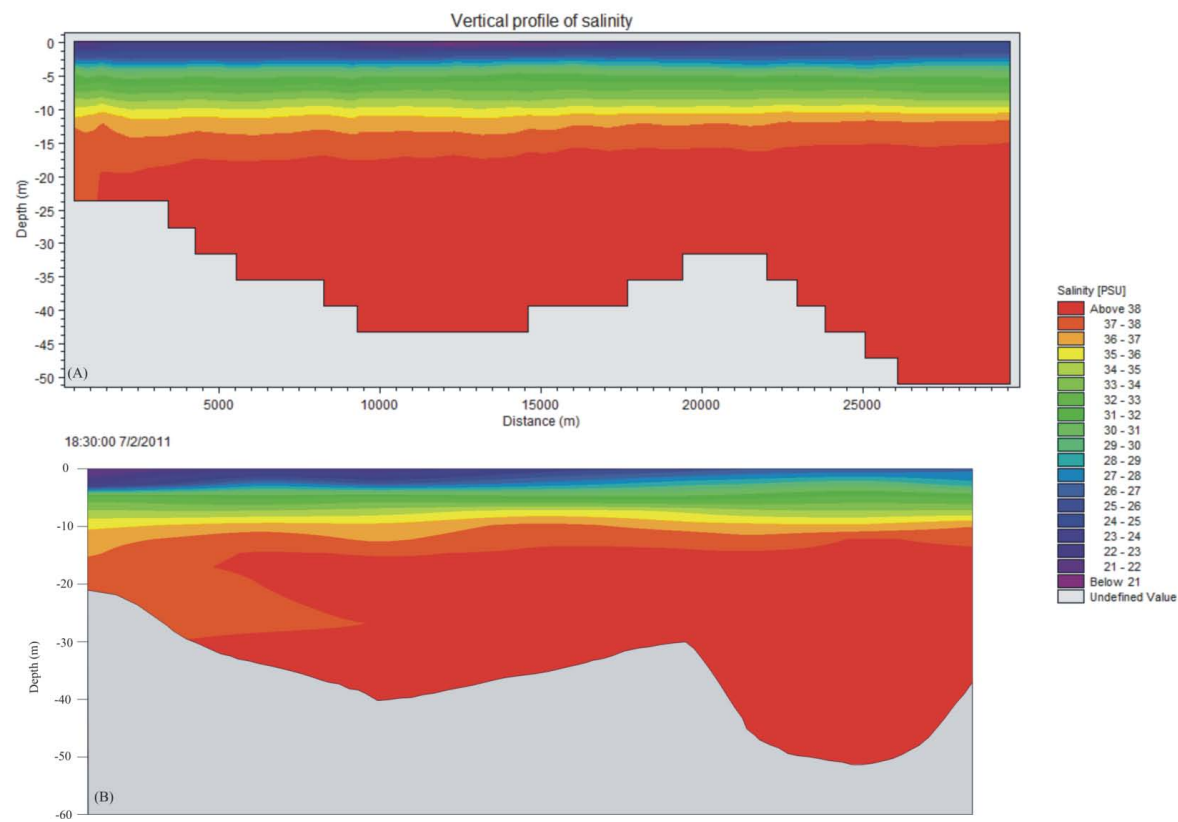

Fig. 7. Snapshot of hydrodynamic circulation along a transect from the mouth to the head of the enclosed gulf, using MIKE 3 HD. The first picture (a)represents the salinity distribution along the transect, as the model simulate it. The second picture (b) represents the observed salinity distribution along the same transect.
Annual hypoxia dynamics in an enclosed gulf

K. Kountoura and I. Zacharias

Title Page

Abstract Introduction

Conclusions

References

Tables

Figures

14

4

Back

Full Screen / Esc

Printer-friendly Version

Interactive Discussion 


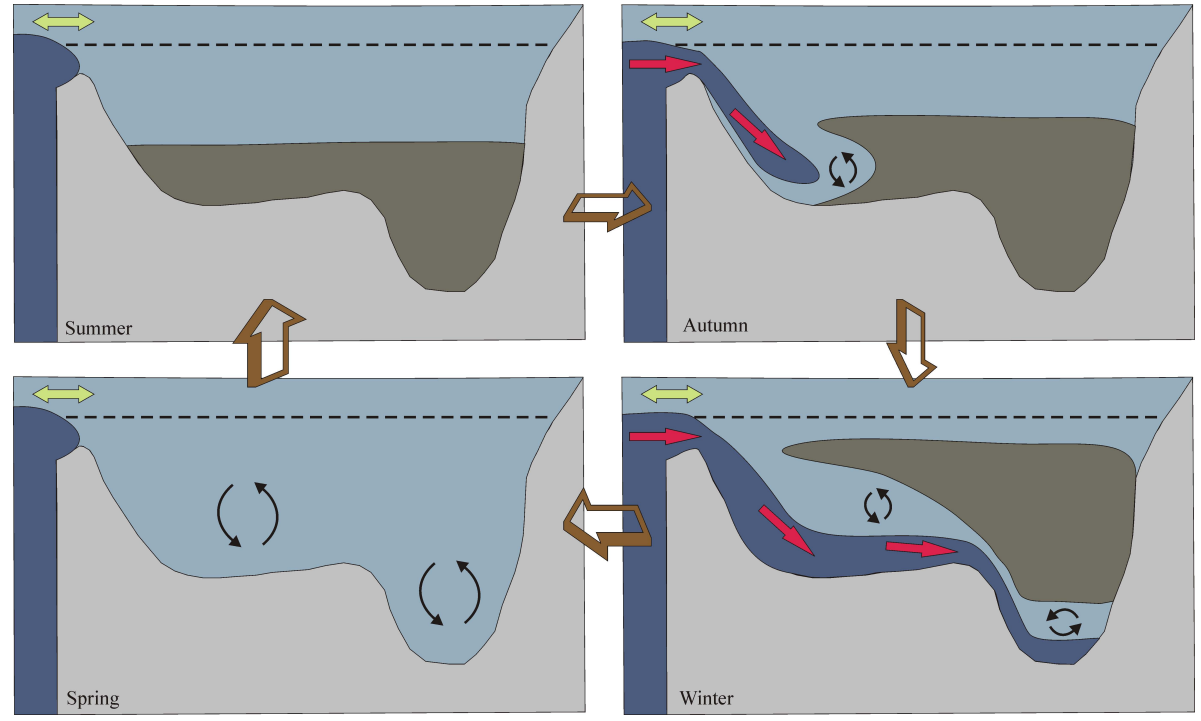

Fig. 8. Schematic view of the "Bottom Hypoxic Water Zone" (BHWZ) dynamic during the year. The black, dashed line represents the pycnocline which exists in the water column almost throughout the year, the red arrows represent the intrusion of the "Open Sea Water Mass" (OSWM), the green arrows mean that above the pycnocline the water moves either to the open sea or to the enclosed gulf and this movement depends on the tide, while the couple of black arrows show the mixing process in deep waters.
BGD

$9,5049-5071,2012$

Annual hypoxia dynamics in an enclosed gulf

K. Kountoura and

I. Zacharias

\section{Title Page}

\section{Abstract} Introduction

Conclusions

References

Tables

Figures

14

4

Back

Close

\section{Full Screen / Esc}

Printer-friendly Version

Interactive Discussion 